\title{
Torture and State Violence in the United States: A Short Documentary History
}

\author{
The John Hopkins University Press Baltimore 2011; ISBN: 978-1-14214-0249-9 \\ By Robert M. Pallitto, Ed.
}

Kristine A Huskey, JD, Professor of Practice and Director*

Given recent revelations confirming the involvement of high-level U.S. government officials in establishing and implementing the torture and abuse of detainees, Robert M. Pallitto's book on U.S. torture and state violence is a must read. Since publication, the book has certainly been a major contribution to the ongoing torture debate in America. Yet, its significance in telling the long chronological story of cruelty and torture in the United States has been further illuminated by the 2013 report on U.S. state-sponsored torture issued by The Constitution Project's Task Force on Detainee Treatment. The book is thus both a cornerstone in the historical annals on torture and a premonition of what would be the undeniable truth: in the past decade, the systematic and widespread use of torture and cruelty was a matter of United States policy and practice.

To begin with, Torture and State Violence is indeed a "documentary history" and as such is one of the first and most comprehensive reference works on the subject of state violence in the United States. The author has

\footnotetext{
^) University of Arizona James E. Rogers College of Law Correspondence to: khuskey@email.arizona.edu
}

compiled over 120 records that date back 400 years to the pre-birth of America. The documents are organized around five broad periods in history: colonial North America and the early republic; slavery and the frontier; imperialism, Jim Crow and the world wars; the Cold War, Vietnam and police action; and, lastly, the War on Terror. Importantly, the documents all originate from government sources and include materials such as attorney general opinions, internal agency memoranda, testimony by government officials, court opinions, and international treaties of which the United States is a signatory.

Second, Pallitto provides a highly effective introduction, which raises profound questions and serves as a framework for digesting the raw materials. Although the book includes documents from, and addresses periods of history, well before the "war on terror," the Introduction makes clear it is the current post-9/11 period, which, in shining a spotlight on state-sponsored cruelty, forces us to think through concepts such as liberalism, democracy and torture and their relationship to one another.

By "liberalism," the author refers not to the political label but rather to the political philosophy with its roots in the Enlightenment Age, that is, the ideology that aims for the obtainment of political conditions necessary for exercising personal freedoms 
and equality. In this sense then, we begin to understand his quest. As the notions of American democracy and individual rights developed, so too did the move away from the public display of cruelty on bodies by state actors as a means of deterrence toward what can be understood as secret or stealthy torture. Secret torture is essentially recognition by the state that despite its own arguments of necessity, the state "has more to lose by being discovered as cruel than it has to gain by collecting counterterror intelligence."

The author then moves into explaining three different understandings of "torture": the historical, the socially constructed, and the legal. Perhaps the most disquieting is the section on "Torture as a Matter of Law" as it is a reminder that states, the United States being no exception, have readily used the word, "torture," simply as a way to characterize what the state is not doing. The state can do this as long as there are government actors willing to engage in such semantics. In the "war on terror," those actors were lawyers and health care professionals. Herein lies perhaps a gap in the book. There is substantial evidence demonstrating the involvement of government psychologists and doctors in the creation, implementation and monitoring of the torture and abuse of detainees at Guantanamo, Abu Ghraib and elsewhere, yet there is no discussion of the role of health care professionals in the "war on terror." The ability of a state to hijack a profession to carry out its policies and thereby put a veneer of legitimacy on such policies embodies the idea of state-sponsored cruelty in its highest form. Without the participation of both the legal and the medical professions, the Bush Administration would have been unable to assert it was not engaging in torture.

Pallitto does a very effective job of addressing the infamous "torture memos" written during the Bush Administration by Assistant Attorney General Jay Bybee and John Yoo in the Office of Legal Counsel at the U.S. Department of Justice, which essentially set forth a definition in which almost anything short of organ failure or death was not torture. He understandably expresses concern about "pinning down" an exact definition of torture because it allows the state to "green-light certain interrogation practices by calling them something short of torture" as well as draw a false line between torture and other cruel practices. Yet, as an attorney, I have difficulty not drawing a line between what is legal and what is illegal because I believe that in times of crises, what is thought necessary - moral or immoral can sometimes only be stopped short by what is designated as illegal. My sentiment notwithstanding, I do agree with the author that the meaning of torture goes deeper than positive law.

This part of the book is a thoughtful segue to the next section which addresses the potential for conflict between human or civil rights and democracy, citing the Patriot Act and the Military Commissions Act of 2006, both statutes passed by a democraticallyelected Congress and both of which drastically infringed on individual rights in the name of national security.

With the Introduction and some profound questions in hand, the reader moves into the main portion of the book. Here, the author has laid out in chronological fashion the evidence, letting the documents largely speak for themselves. It is, at times, almost unbelievable, to read of the cruelty carried out on behalf of the state. Particularly horrifying are the materials documenting the legally permissible treatment of slaves and the treatment of other minorities, such as Native Americans and Filipinos, through 
history. The continuity of cruelty is chilling, particularly because the author has included the many anti-torture and pro-human rights documents to which the United States made a public commitment, including the Universal Declaration of Human Rights, the Geneva Conventions, the International Covenant on Civil and Political Rights, and the Convention against Torture and Other Cruel, Inhuman and Degrading Treatment.

The book's Conclusion reinforces some of the themes raised in the Introduction but also reminds us that the continuity of dissention is present in the documents, that is, examples of state officials challenging - at personal risk - violent state practices. This provides a glimmer of hope as Torture and StateViolence is not merely an historical accounting. It is also meant to be forward looking, drawing upon the past to assist in thinking about the future and the role of the state in cruel treatment. In this regard, Pallitto raises an aspect that is often lost among popular discussion of necessity, on the one hand, and accountability, on the other. That is, the significance of the person being tortured. Failure to place prominence on the voice of the victim in discussing torture moves us away from the topic of torture itself. Pallitto's aim of his illustrious work is primarily to engender a rethinking of the place of torture in anti-terror policy. As he eloquently states, torture is not just a transgression of the ban on torture; the ban is symbolic of a "commitment to a whole set of ideas about how human beings may be treated, and how transgression of that ban places the larger commitment in jeopardy, threatening to replace a 'liberal culture' with a 'torture culture'." 